\title{
Judi Online Dikalangan Remaja (Kasus Kelurahan Bone - Bone, Luwu)
}

\author{
On Line Gambling Among Adolescents \\ (The Case of Bone, Luwu)
}

\author{
M. Ramli AT.'; Andi Haris ${ }^{2}$; Heru ${ }^{3}$; Andi Rusdayani A* \\ ${ }^{1.2 .3}$ Departemen Sosiologi, Fakultas Ilmu Sosial dan Ilmu Politik Universitas Hasanuddin \\ ${ }^{4}$ Department Agricultural Cultivation, Fakultas Ilmu Sosial dan Ilmu Politik Universitas Hasanuddin \\ Email Coresponden: mramliat@yahoo.com ${ }^{1}$; aharis2000@yahoo.com ${ }^{2}$
}

\section{A R T I C L E I N F O}

\section{How to Cite:}

AT, M. R., Haris, A., Heru, \& A, A. R. (2019). Judi Online dilakangan Remaja (Kasus Kelurahan Bone-Bone, Luwu). Hasanuddin Journal of Sociology (HJS), 1(2), 127138.

\section{Keywords: \\ Gambling, On-line, Luwu, Adolescents}

\section{Kata Kunci :}

Judi, On-Line, Luwu, Remaja.

\begin{abstract}
A B S T R A C T
Deviant behavior is a conscious action conducted by a person due to various reasons which is similar to adolescents who involved in online gambling. They realized that gambling is a deviant behavior and it is considered bad by many people and it is forbidden by the law. However, it does not stop them to involve in that kind of activity. The objective of the study was to explain the characteristics of adolescents in online gambling, the effects of online gambling, and the survival factor of online gambling. This study used qualitative descriptive method. The research location was at Bone urban village-Bone, North Luwu District. Data collection method used role observation, structured interview, and documentation. Information as data source in this study was adolescents at Bone urban village-Bone, North Luwu District.
\end{abstract}

\begin{abstract}
ABSTRAK
Perilaku menyimpan merupakan suatu tindakan yang dilakukan secara sadar oleh seseorang berlandaskan atas berbagai alasan, sama halnya dengan remaja yang terlibat dalam permainan judi online, secara sadar mereka mengetahui bahwa perjudian termasuk dalam perilaku menyimpang yang dipandang tak baik oleh sebagaian masyarakat serta dilarang oleh hukum Negara, namun hal tersebut tidak menutupi ketertarikan mereka ikut serta didalamnya. Penelitian ini bertujuan untuk menjelaskan karakterisristik remaja pelaku judi online dampak dari judi online faktor penyebab bertahanya judi online. Penelitian ini menggunkan metode kualitatif deskriptif dengan memillih lokasi dikelurahan bone bone, Kabupaten Luwu Utara. Metode pengumpulan data yang digunakan adalah pengamatan berperan serta wawancara struktur dan dokumentasi. Informasi sebagai sumber data dalam penelitian ini adalah remaja yang berada dikelurahan bone - bone, Kabupaten Luwu Utara.
\end{abstract}




\section{PENDAHULUAN}

Perkembangan teknologi informasi semakin hari semakin modern. Awalnya Komputer yang kita kenal dahulu, menggunakan layar tabung. Saat ini teknologi semakin praktis dengan hadirnya LCD dan komputer portable yang sekarang ini juga banyak sekali di jual, untuk komputer versi portabelnya atau yang lebih sering disebut laptop sekarang ada keluaran jenis terbarunya buku yang dinamakan notebook.

Pesatnya perkembangan teknologi bukan hanya terjadi pada teknologi komputer, namun beriring dengan teknologi seluler, untuk dunia mobile sekarang, telepon seluler sudah menjadi bagian dari gaya hidup masyarakat Indonesia sebagai alat komunikasi, dulu telepon seluler hanya dimiliki oleh orang kaya dan orang tertentu saja, tapi sekarang telepon seluler telah menjadi sebuah kebutuhan pokok bagi komunikasi masyarakat, sekarang fungsi telepon seluler selain berfungsi untuk alat komunikasi juga biasa untuk internet, multimedia dan entertainment, hal ini tentunya memberikan kemudahan sekaligus nilai tambah bagi masyarakat pemakaiannya untuk keperluan pengaksesan data dan informasi, teknologi yang sangat berperan dalam pengembangan generasi nirkabel ini antara lain adalah teknologi $W I-F i$ dan $4 G$ sekarang ini hampir semua telepon seluler dan laptop sudah memiliki fasilitas $W i-F i$ dan $4 G$. Sehingga membuat kita dapat mengakses informasi dengan lebih cepat.

Segala aspek ke hidupan sehari-hari sangat berpengaruh oleh adanya perkembangan teknologi tersebut, tidak dapat dipungkiri bahwa dengan semakin berkembanganya teknologi akan mempermudah segala aktivitas kehidupan manusia keterbatasan jarak yang memisahkan antara satu individu dengan individu lain dapat di kesampingkan dengan semakin berkembangnya teknologi bahkan sekarang ini kita bisa saling sapa tanpa harus bertemu secara fisik seperti, panggilan video atau video call.

Walt rostow dan Daniel lerner (dalam Liliweri, 2013 :404 ) mengungkapkan bahwa disuatu waktu kelak pola - pola perilaku institusi dan perilaku kita tergantung pada pemanfaatan teknologi demi mempertahankan pembangunan yang berkelanjutan, termasuk pembangunan ekonomi, kehidupan manusia dan teknologi adalah citra masa depan, teknologi hadir untuk memudahkan hampir disemua aktivitas manusia, aktivitas ekonomi, sosial dan budaya menjadi lebih muda.

Sebagai pengguna internet aktif, kita dapat menemukan sebuah fenomena bahwa internet tidak hanya digunakan sebagai media yang memudahkan manusia melakukan kegiatannya saja, akan tetapi juga terdapat beberapa pihak yang menggunakan internet dengan cara yang berbeda, selain dapat melakukan hal -hal yang positif, user atau pengguna juga dapat terjerumus pada hal-hal yang negatif seperti, menonton video porno, penipuan, penculikan, pemalsuan bahkan saat ini judi dapat dilakukan secara online.

Perjudian dalam jaringan (daring) saat ini berkembang dengan pesat, awalnya perjudian online 
hanya berupa game kartu, saat ini dari judi tebak skor pertandingan sepak bola hingga sabung ayam banyak menjamur di situs-situs lokal maupun mancanegara, seperti SBObet Dewa poker BETWIN303 dan memiliki user untuk melakukan transaksi judi, permainan judi online cukup sangat praktis untuk dilakukan serta faktor perkembangan fasilitas yang mendukung. Pertumbuhan judi online yang berkembang pesat di dunia maya ternyata kurang diantisipasi pemerintah, fokus, ke pornografi melalui UU anti pornografi pemerintah seakan membiarkan judi online yang terdaftar yayasan DNS nawala Menurut pengelola yayasan nawala Irwin day, pertumbuhan judi online yang pesat juga salah satunya dipicu oleh pembiaran yang dilakukan internet aservice provider mengingat biasanya pelaku judi online merupakan pelanggan besar dari ISP yang bersangkutan, dalam (merdeka.com) beliau menyatakan "meski situsnya jumlahnya lebih sedikit dari situs pornografi, tapi pengaksesannya 25 yang terbanyak, bahkan yang masuk kedalam 25 besar situs yang diakses paling besar di Indonesia, beliau juga menambahkan pemerintah ternyata tidak memiliki.

\section{METODE PENELITIAN}

\section{- Pendekatan strategi penelitian}

Penelitian ini menggunakan metode penelitian deskriptif dengan menggunakan pendekatan kualitatif, penelitian yang berusaha mendeskripsikan suatu gejala, peristiwa yang terjadi saat sekarang. Penelitian deskriptif memusatkan perhatian pada masalah, aktual sebab sebagaimana adanya pada saat penelitian berlangsung. Melalui penelitian deskriptif, peneliti berusaha mendeskripsikan peristiwa dan kejadian yang menjadi pusat perhatian tanpa memberikan perlakuan khusus terhadap peristiwa tersebut (Noor 2011:34-35)

Penelitian kualitatif sasaran kajian atau masalah penelitian merupakan suatu satuan yang bulat atau menyeluruh yang dikaji dengan cara memahami dan bukan dengan cara mengukur, sasaran kajian yang dipandang sebagai satuan yang bulat dan menyeluruh (whole a system ) tersebut merupakan corak pandang yang dinamakan juga sebagai penelitian yang bersifat holistic, menurut denzin dan Lincoln kata kualitatif menyiratkan penekanan pada proses dan makna yang tidak dikaji secara ketat atau belum diukur dari sisi kuantitas, jumlah intensitas, atau frekuensinya (Noor 2011: 34)

\section{- Lokasi penelitian dan waktu penelitian}

Penelitian ini akan dilaksanakan di bone-bone, Kabupaten Luwu Utara, peneliti merupakan salah satu mantan pemain judi online dikalangan remaja kelurahan bone -bone, Kabupaten Luwu Utara 
Penelitian ini dilaksanakan selama kurang lebih 1 bulan, yaitu mulai awal bulan april hingga selesai pada awal bulan mei 2019, penelitian terhitung hingga terselesaikannya proposal ini

\section{- Teknik pengumpulan data}

Proses pengumpulan data merupakan hal utama yang dilakukan dalam penelitian pada penelitian ini ada dua jenis data yang akan dikumpulkan, berdasarkan sumber pengambilan data yaitu data primer dan data sekunder.

\section{- Wawancara}

Wawancara merupakan salah satu teknik pengumpulan data yang dilakukan dengan berhadapan secara langsung dengan yang diwawancara tetapi dapat juga diberikan daftar pertanyaan dahulu untuk dijawab pada kesempatan (Noor,2011 : 138 ). Proses wawancara dilakukan oleh peneliti terhadap responden terkait dengan judul penelitian yaitu judi online dikalangan remaja kelurahan bone-bone Kabupaten Luwu Utara yang memungkinan menjawab rumusan masalah yang telah ditentukan oleh peneliti, teknis yang dilakukan peneliti dengan mendatangi rumah informan, tempat kerja dan tempat dimana informan dan tempat dimana informan bisa diwawancarai dengan tetap mengacu pada kriteria informan yang harus diwawancarai. Estreberg (2002) mendefinisikan interview sebagai berikut " $A$ meeting of two perseons to exchange information and ide through question and reponses, resulting in communication and joint construction of meaning about a particular topic " wawancara merupakan pertemuan dua orang untuk bertukar informasi dan ide melalui tanya jawab sehingga dapat dikonstrusikan makna dalam satu topik tertentu .

Wawancara digunakan sebagai teknik pengumpulan data apabila peneliti ingin melakukan studi pendahuluan untuk menemukan permasalah yang harus diteliti, tetapi juga apabila peneliti ingin mengetahui hal-hal dari responden yang lebih mendalam. Teknik pengumpulan data ini mendasar pada laporan tentang diri sendiri atau selft-report, atau setidak-tidaknya pada pengetahuan dan atau keyakinan pribadi.

\section{- Observasi}

Teknik ini menuntut adanya pengamatan dari peneliti baik secara langsung maupun tidak langsung terhadap objek penelitian. Instrumen yang dapat digunakan yaitu lembar pengamatan, panduan pengamatan. Beberapa informasi yang diperoleh dari hasil observasi antara lain: ruang (tempat), pelaku, kegiatan, objek, perbuatan, kejadian atau peristiwa, waktu dan perasaan. Alasan peneliti melakukan observasi yaitu untuk menyajikan gambaran realistis perilaku atau kejadian, menjawab pertanyaan, membantu mengerti perilaku manusia, dan evaluasi yaitu melakukan pengukuran terhadap aspek tertentu melakukan umpan balik terhadap pengukuran tersebut (Noor,2011: 
140 ). Secara teknis peneliti mencari informasi tambahan terkait rumusan masalah dari lingkungan sekitar dan menjadi bahan pendukung dalam penelitian ini .

\section{- Dokumentasi}

Dokumentasi yang dimaksudkan dalam hal ini adalah laporan dan hasil penelitian sebelumnya serta jurnal yang terkait dengan hasil penelitian adapun teknik yang akan dilakukan peneliti dalam mengumpulkan dokumentasi yaitu mencari arsip penelitian -penelitian sebelumnya baik dalam perpustakaan maupun di penyedia jurnal yang dapat di akses via internet termasuk pemberitaan media elektronik

\section{- Teknik analisis data}

Analisis data dalam penelitian kualitatif, dilakukan pada saat pengumpulan data berlangsung dan setelah selesai pengumpulan data dalam periode tertentu. Pada saat wawancara, peneliti sudah melakukan analisis terhadap jawaban yang diwawancarai bila jawaban yang diwawancarai setelah analisa terasa belum memuaskan, maka peneliti akan melanjutkan pertanyaan lagi, sampai tahap tertentu, diperoleh data yang dianggap kredibel, miles dan huberman (sugiyono,2013), mengemukakan bahwa aktivitas dalam analisis data yaitu reduksi data penyajian dan penarikan kesimpulan.

\section{- Reduksi data}

Data yang diperoleh dilapangan cukup banyak,untuk itu perlu dicatat secara teliti dan rinci, seperti telah dikemukakan, semakin lama peneliti di lapangan maka jumlah data akan semakin banyak, kompleks dan rumit. Untuk itu perlu segera dilakukan analisis data melalui reduksi data. Meredukasi data berarti merangkum memilih hal -hal yang pokok, memfokuskan pada hal-hal yang penting, dicari tema dan polanya. Dengan demikian data yang telah di reduksi akan memberikan gambaran yang lebih jelas, dan mempermudah peneliti dalam melakukan pengumpulan data selanjutnya, dan mencarinya bila diperlukan.

\section{- Penyajian data}

Setelah data direduksi, maka langkah selanjutnya adalah men-display data. Dalam penelitian kualitatif, penyajian data bisa dilakukan dalam bentuk uraian singkat, bagan, hubungan antar kategori flowchart dan sejenisnya. Dalam hal ini miles dan huberman (sugiyono ,3013:249) menyatakan yang paling sering digunakan untuk menyajikan data dalam penelitian kualitatif adalah dengan teks yang bersifat naratif. Dengan mendisplaykan data, maka akan memudahkan untuk memahami apa yang terjadi, merencanakan kerja selanjutnya berdasarkan apa yang telah dipahami tersebut.

\section{- Penarikan kesimpulan}


Langkah ke tiga dalam analisis data kualitatif menurut Miles dan Huberman adalah penarikan kesimpulan dan verifikasi. Kesimpulan awal yang dikemukakan masih bersifat sementara, dan akan berubah bila tidak ditemukan bukti -bukti yang kuat yang mendukung pada tahap pengumpulan data berikutnya. Tetapi apabila kesimpulan yang dikemukakan pada tahap awal didukung oleh bukti -bukti yang valid dan konsisten saat peneliti kembali ke lapangan mengumpulkan data, maka kesimpulan yang dikemukakan merupakan kesimpulan yang kredibel.

\section{HASIL PENELITIAN DAN PEMBAHASAN}

\section{- Dampak judi online terhadap remaja di kelurahan Bone-bone}

Fenomena judi online tentunya memiliki dampak bagi penggunanya, baik dampak positif maupun dampak negatif, berjudi merupakan patologi sosial yang berdampak negatif bagi pelakunya.

Jika dampak positifnya adalah mendapatkan keuntungan dan menambah materi dalam pemenuhan mereka (remaja), tentunya ada dampak negatif yang dirasakan oleh remaja seperti sulitnya membagi waktu bersama keluarga dan kecanduan terhadap judi online .

\section{- Sulitnya Membagi Waktu Bersama Keluarga}

Dampak negatif yang sering dirasakan oleh remaja yang melakukan judi online adalah sulitnya untuk membagi waktu bersama keluarga. Hal ini disebabkan karena pemain judi online atau terkadang memilih di dalam kamar untuk bermain judi online agar tidak diketahui oleh orang tuanya, seperti yang dikatakan oleh informan $\mathrm{Al}$ :

Jarang ka ketemu sama keluargaku karna kalau ka main poker pergi ka ke warnet atau workop, jadi kalau sudah mka sarapan langsung ke warnet mka itu main poker,paling 3 kali dalam sehari kak ketemu sama keluargaku, itupun kalau mau makan (Wawancara informan A1,22 April 2019)

Hal serupa dengan yang dikatakan oleh informan A7 dan informan A6. Dalam wawancara yang dilakukan oleh peneliti kepada informan A7 dan A6, peneliti mengetahui bahwa judi online menyebabkan susah informan dalam membagi waktu untuk bertemu bersama keluarganya. Mereka mengakui dalam membagi waktu untuk bertemu sesama keluarganya, yaitu di waktu pagi dan malam. Mereka memilih menghabiskan waktunya di warung kopi (warkop) dan warug internet (warnet) untuk bermain judi online

Berbeda dengan yang dikatakan oleh informan A2, informan cenderung lebih sering bertemu dengan keluarganya, menurut pengakuan A2, bahwa judi online bukanlah salah satu hal yang bisa membatasi waktunya untuk bertemu dan berkumpul bersama keluarganya. Berikut hasil wawancara 
bersama informan A2 :

Kalau masalah bertemu sama keluarga masih sering ,karena main judi online itu hanya sebatas hoby dan hiburan di waktu luang (wawancara informan A2,20 April 2019)

Sama halnya yang dilakukan oleh informan A3. Menurut pengakuanya ia masih sering bertemu bersama keluarganya karena menurutnya bermain judi online hanya merupakan sebatas hoby dan pekerjaan sampingan. Jadi bermain judi online bukanlah salah satu hal yang dapat membatasinya untuk berkumpul dan bertemua bersama keluarganya. Berikut hasil wawancara bersama informan A3 :

Saya masih sering bertemu keluarga ,karena judi online hanya sebatas hoby dan pekerjaan sampingan,jadi saya bias diabatasi untuk bermain poker . ( poker A3 ,20,April 2019)

\section{- Kecanduan}

Dampak negatif yang kedua selain sulitnya membagi waktu bersama keluarga adalah kecanduan bermain judi online, inilah yang paling memberi efek buruk dalam kehidupan remaja pelaku judi online Seperti yang dikatakan oleh informan A1:

Kalau orang ketagiah main judi online pasti sampai jual barang -barangnya atau nagaidakan barang -barangnya supaya ada lagi uangku napake deposit ,Biasa juga pergi pinjam uanganya temanya ( wawancara informan A1,22 April 2019)

Pernyataan informan A1, menjurus pada ketakutan-ketakutan yang mengarah pada perilaku menghalalkan segala cara. Memang informan A1 tidak mejelaskan secara langsung perilaku-perilaku apa saja yang dilakukan oleh remaja yang telah ketagihan atau kecanduan bermain judi online, tetapi dalam beberapa hal, seseorang yang telah candu bermain judi online, itu akan merusak dirinya sendiri.

Ketagihan bermain judi online dapat memberikan dampak yang buruk bagi pelaku judi online. Rasa ketagihan ini akan mendorong seseorang untuk selalu ingin memainkan judi online. Rasa ketagihan ini akan mendorong seseorang untuk selalu ingin memainkan judi online dan mereka yang ketagihan akan melakukan apa saja untuk memenuhi keinginanya untuk bermain judi online, dan mereka yang ketagihan akan melakukan apa saja unuk memenuhi keinginanya untuk bermain judi online, dan mereka yang ketagihan akan melakukan apa saja untuk memenuhi keinginanya untuk bermain judi online. Mulai dari meminjam uang, menjual dan menggadaikan barang-barangnya seperti laptop, motor, telepon genggam dll. Seperti yang dikatakan oleh informan A1:

Saya itu biasa pinjam ka uangnya kakakku untuk deposit lagi ,jadi alasanku itu mau ka peke perbaiki motorku atau pake kupake beli pulsa data,Kalau mdak dikasi pinjam ja uangnya kakakku, terpaksa kugadaikan Hp ku, terpaksa kusuruh temanku beli itu Hp ku biar tidk putta (barang yang digadaikan tidak ditebus). (wawancara informan A1,22, April 2019) 
Hal yang sama diungkapkan oleh informan A4:

Tidak bisaka tahan kalau mau sekali main ,pernah itu uang SPP ku kuputar jadi modal kupake main, itu hari ka senirku dapt jackpot lima juta .tergoda ka lihati ,jadi kuputar mi uang SPP kupake mai qiu-qiu sama pasang parlay,Pernah juga kegadaikan laptopku sama motorku ,terus uanya itu kuputar mi pake main pker sama pasang parlay ,Ndak bias sekali ditahan permainan begini kalau pintar mki main ,apalagi sering ki menang besar ,pasti penasaran ters ki ,mau teruski menang (wawancara informan A4,21 April 2019 )

Berdasarkan hasil wawancara bersama informan A4 ,peneliti mengetahui bahwa informan melakukan segala cara untuk mendapatkan modal untuk bermain judi online. Seperti dari pengakuan informan A4 yang sampai menggunakan uang SPP kuliahnya untuk bermain judi online, dan informan A4 juga pernah mengadaikan barang -barang berharganya seperti laptop, telepon genggamnya dan sepeda motornya.

Demi mendapatkan uang untuk bermain judi online, informan A4 juga mengakui bahwa ketika kita sudah pandai dan pernah mendapatkan kemenangan besar dalam bermain judi online, maka kita akan susah untuk tidak memainkan permainan judi online, maka kita kan susah untuk memainkan permainan judi online tersebut karena selalu dibayangi oleh rasa penasaran dan rasa ingin terus menang.

Hal serupa yang dikatakan oleh informan A5. Dalam wawancara bersama informan, ia mengakui susah menahan untuk tidak bermain judi online dan selalu merasa tergoda ketika ia melihat orang bermain judi online dan mendapatkan kemenangan besar. Demi agar bias bermain judi online, informan A5 juga melakukan segala cara untuk mendapatakan uang sebagai modal bermain. Seperti, menggadaikan telepon seluler, meminta uang kepada orang tuanya dan sampai menjual ayamnya .

Berikut wawancara bersama informan A5 :

Biasanya kalau mau sekalika main, nah ndak ada sekalimi modalku pake main,pergi ka gadaikan Hpku atau mint aka uangnya mamaku pake main poker.Pernah juga pergika jual ayamku di mama -mama jawa (pembeli ayam ) yang penting ada bisa di deposit ,Susah sekali ki tahan kalu mau sekali mki main ,apalagi kalau lihat ki orang main nah banyak nature uang ,pasti tergodaki (wawancara informan A5,17 Mei 2019)

Berbeda dengan yang dikatakan oleh yang dikatakan oleh informan A6:

Saya kalau ndak ada mimodal ku pake main , berhenti mka itu ,Ndak mau ka saya main panas.Ndak pernah jka saya sampai gadaikan barang -barang atau sampai sampai jual barang -barang ...Banyak memang orang sampai gadai barang - barangnya tapi saya ndak berani ka .Jadi adapi lagi modal baru mainka (wawancaa informan A6,17 Mei 2017)

Senada dengan yang dikatakan dalam wawancara bersama informan A8. Selama bermain judi online, informan A8 mengaku tidak pernah meminjam uang dari orang lain. Menurut pengakuan 
informan A8, ia juga tidak pernah menggadaikan barang -barang berharganya demi mendapatkan uang untuk bermain judi online .

Berikut wawancara bersama informan A8:

Ndak pernah ka saya mau pinjam -pinjam uangnya orang atau sampai gadai baraang barangku. Ada pi modalku saya baru main ka ,jadi ndak ada modalku ndak mainka .Kalau dampai gadai barang -barang nah tidak bisaki tebusi ,apami mau dibilang sama orang tuata (wawancara informan A8, 14 Mei 2019)

Hal senada dengan yang diungkapkan oleh informan A3 :

Kebanyakan memang orang ,ada yang sampai menggadaikan dan menjaual barang barang berharganya,Tetapu saya sebagai pemain judi online belum pernah seperti itu, walaupun saya [ernah kalah besar bermain judi online tetapi saya menggadaikan dan menjual barang -barang. Saya anggap judi online hanya sebatas pengisi waktu luang di waktu bekerja .(wawancara informan A3, 20 April 2019 ).

Dari hasil wawancara bersama informan A3, peneliti mengetahui bahwa informan A3 menganggap bermain judi online hanyalah sebagai pengisi waktu luang di saat sedang bekerja, informan A3 juga mengaku tidak pernah menggadaikan barang -barang berharganya demi mendapatkan uang sebagai modal untuk bermain judi online .

Rasa ketagihan ini bermula dari rasa puas dialami oleh pemain judi online saat mereka (remaja) memperoleh kemenangan yang besar. Kemenangan yang besar menimbulkan rasa penasaran dan mendorong mereka (remaja) untuk terus bermain dan membuat mereka (remaja) sampai kecanduan akan permaina online tersebut.

Sulitnya membagi waktu untuk bertemu, berkumpul, bersama keluarga dan menjadi kecanduan yang mendorong remaja di kelurahan Bone-bone melakukan dan menghalalkan segala cara untuk memenuhi keinginannya memainkan permainan judi online adalah dampak negatif yang dirasakan oleh rema di kelurahana Bone -bone dalam memainkan permainan judi online

\section{- Memenuhui kebutuhan sehari - hari}

Perjudian online tidak hanya memiliki dampak negatif bagi penggunanya tetapi juga memiliki dampak positif bagi penggunanya. Untuk memenuhi kebutuhan sehari -hari, kebanyakan remaja memilih untuk menjadi pengguna situs perjudian online sebagai alternatif untuk mendapatkan penghasilan. Seperti yang dikatakan oleh informan A4:

Biasanya itu hasil kemenanganku kupake beli rokok, makanan ,bajju sama biasa juga kupake mabuk -mabuk sama temanku, menurutku hasil kemenanganku itu bias penuhi kebutuhan sehari-hariku (wawancara informan A4 ,21 April 2019)

Dari hasil wawancara diatas, peneliti mengetahui bahwa dengan menjadi pengguna situs 
perjudian online, informan A4 memenuhi kebutuhan sehari-hari nya informan A4, biasanya menggunakan hasil kemenangan dalam bermain judi online untuk membeli makan, rokok, baju dan untuk mabuk - mabukan bersama temanya

Hal senada dengan yang dikatakan oleh informan A5

Kalau menangka uangnya itu kupake traktir temanku, beli rokok, makan tramadol (obat penenang ) sama sabu-sabu, sama pernahka juga beli Hp pake uang menangku.Kalau menangka bisa napenuhi kebutuhan sehari-hariku .(wawancara informan A5, 17 Mei 2019

Dari hasil wawancara bersama informan A5, peneliti mengetahui bahwa informan A5 memilih menjadi pengguna situs perjudian online sebagai alternatif untuk mendapatkan penghasilan secara instan agar bisa memenuhi kebutuhan sahari-harinya. Ketika menang dalam bermain judi online ,informan A5 memanfaatkan hasil kemenanganya untuk memenuhi kebutuhan sahari -harinya seperti membeli rokok membeli makanan, membeli pakaian, dan bahkan informan A5 menggunakan uang hasil kemenangannya untuk membeli obat tramadol (obat penenang) dan sabu-sabu. Informan A5 juga pernah membeli telepon genggam dengan menggunakan hasil kemenanganya .

\section{KESIMPULAN}

Berdasarkan dari pembahasan bab-bab sebelumnya maka dapat diambil kesimpulan sebagai berikut :

1. Memainkan judi online, pemain harus memiliki tiga modal, yang pertama adalah modal pengetahuan yang membantu kita dalam mengakses situs perjudian online.

Kedua, modal buku rekening tabungan, buku rekening tabungan merupakan syarat untuk mendaftar atau membut sehingga kita adaptasi bermain judi online, seperti mengukur kemampuan lawan dan kemampuan mempredikasi kemenangan. Dari tiga modal inilah yang dapat membantu para pemain judi online mendapatkan kemenangan.

2. Praktek perjudian online dimainkan dari berbagai karakteristik dari kalangan remaja. Karena dari wawancara yang dilakukan peneliti, pemain judi online dari kalangan remaja terbagi dari beberapa kategori. Karakteristik pertama adalah pekerjaaan, dimana peneliti mendapatkan remaja yang sudah mempunyai pekerjaan tetap dan belum mempunyai remaja yang sudah mempunyai pekerjaan tetap dan belum mempunyai pekerjaan tetap (pengangguran). Karakteristik kedua adalah pendidikan, dimana peneliti, mendapatkan remaja yang masih duduk di bangku Sekolah Menengah Atas (SMA) dan kuliah ( mahasiswa). Karakateristik ketiga yaitu latar belakang orang tua yang berbeda-beda, mulai dari latar belakang pendidikan, 
pekerjaan, dan penghasilan orang tua pelaku judi online. Karakteristik keempat yaitu pengalaman bermain judi online dari 4 sampai 6 tahun yang dimulai dengan rasa penasaran dan faktor lingkungan pertemanan yang merupakan penyebab utama dalam memulai melakukan praktek judi online dikalangan remaja, dimana dalam lingkungan pelaku hampir semua bermain judi online dikalangan remaja, dimana dalam lingkungan pelaku hampir semua bermain judi online yang dapat menyebabkan remaja yang belum mengetahui judi online ikut terbawa arus pergaulan bermain judi online

3. Tidak terlepas dari dampak yang diperoleh oleh pelaku, judi online juga dapat memberikan dampak negatif dalam kehidupan mereka (remaja). Dorongan yang tidak bisa ditahan membuat para pelaku (remaja) menghalalkan segala cara, seperti mengorbankan uang pembayaran kuliah dan menggadaikan barang-barang berharganya demi permainan judi online. Kecanduan ini akan dialami oleh siapapun (remaja) jika dalam permainan ini, dirinya mendapatkan kemenangan. Kemenangan yang sering didapatnya inilah yang membuat seseorang untuk selalu memainkan dan menjadi candu. Dampaknya yang dirasakan oleh para mahasiswa pelaku judi online adalah sulit membagi waktu bertemu bersama keluarga dan menjadi kecanduan yang mendorong remaja melakukan apapun untuk memenuhi keinginanya memainkan permainan judi online tersebut adalah dampak negatif yang dirasakan oleh remaja dalam memainkan judi online .

4. Perjudian online tidak hanya memiliki dampak negatif bagi penggunanya tetapi juga memiliki dampak positif bagi penggunanya. Untuk memenuhi kebutuhan sehari-hari, kebanyakan mereka (remaja) memilih untuk menjadi pengguna situs perjudian online sebagai alternatif untuk mendapatkan penghasilan tambahan

5. Bertahanya judi online dikalangan remaja di kelurahan Bone-bone bermula dari rasa nyaman yang dirasakan para pelaku dalam mengakses judi online. Menunjang fasilitas seperti keberadaan dan lancarnya jaringan internet membuat para pelaku merasa lebih nyaman dalam bermain judi online juga menjadi salah satu faktor yang menyebabkan bertahanya judi online juga menjadi salah satu faktor yang menyebabkan bertahanya judi online dikalangan remaja dikelurahan Bone -bone. Lemahnya pengawasan dan tidak adanya penggerebekan dari pihak kepolisian mengenai praktek judi online membuat para pelaku (remaja) merasa aman dan melakukan praktek judi online

6. Kurangnya kontrol sosial dari keluarga mengenai pemberian pendidikan keagamaan dan bahayanya melakukan judi online dikalangan remaja dikelurahan Bone-bone. Kurangnya pengawasan dari orang tua membuat para remaja merasa bebas dalam melakukan 
penyimpangan. Faktor lingkungan pertemanan juga menjadi faktor utama penyebab bertahanya judi online Dimana ketika orang-orang disekeliling kita juga sudah terbiasa dalam melakukan penyimpangan sosial, maka lambat laun kita juga akan ikut terbiasa melakukan penyimpangan sosial.

\section{DAFTAR PUSTAKA}

Adipu, Melda, M Wantu, Sastro .,Hamim Udin .(2013). Faktor Yang Menyebabkan Menjamurnya Perjudian Togel di Desa Botu Moitu Kecematan Botu Moitu Kebupaten Boalemo

Arisanti, Septriana H.(2009) ,Upaya Polri Dalam Mengungkap Tindak Pidana perjudian dikalangan Masyarakat Berpenghasilan Rendah (Studi di Polres Tranggalek). Skripsi Malang :Univeristas Brawijaya .

Kartono, Kartini.(2011).Patologi Sosial. Jakarta: PT.Raja Grafindo

Setiadi, M Elly.(2015).Pengantar Sosiologi.Jakarta:Penerbit Kencana

Sugiyono. (2017).Metode Penelitian Kuantitatif ,Kualitatif dan R\&D.Bandung: Alfabeta

Willis, Sofyan S. (2014).Remaja dan Masalahnya.Bandung:Penerbit Alfabeta

Yusuf, Muri.(2017).Metode Penelitian Kuantitatif, Kualitatif dan Penelitian Gabungan. Jakarta: Penerbit Kencana 